\title{
Interactive and collaborative technological ecosystems for improving academic motivation and engagement
}

\author{
David Fonseca $^{1}$ D $\cdot$ Francisco José García-Peñalvo ${ }^{2}$ D
}

Published online: 25 July 2019

(c) Springer-Verlag GmbH Germany, part of Springer Nature 2019

The emergence and popularity of Information and Communications Technologies (ICTs) have changed the current educational landscape $[1,2]$. ICTs facilitate individuals' ability to learn anywhere and at any time. In fact, by using ICT, access to knowledge acquisition is not restricted to formal contexts, such as academic institutions [3]. In the teaching and learning processes, technology is becoming constantly present and is continuously evolving and changing [4-6]. For this reason, it is necessary that both teachers and students are motivated to apply and engage in the process [7-9], something that can be easy to assume though not always true [10].

ICTs allow individuals to learn anywhere and at any time. In fact, by using ICTs, access to past knowledge is not restricted to formal contexts such as the institutions, and students can acquire skills during their daily life in informal environments [11-16]. The incorporation of open participation in order to improve the social engagement in research projects, as well as the new educational approaches based on gamification and collaborative interaction with the context and the learning process, is modifying the role of the teacher, whose functions are changing $[17,18]$. However, project-based learning (PBL), scenario-centered curriculum (SCC), personal learning environments and networks (PLE \& PLN), flipped methods, programming of robots, the use of wearables for augmented virtual reality, MOOCs, online systems, etc., are technologies [12, 17-30] and concepts that can generate "Good Educational Practice" if the motivation of the teachers and students is the correct one [5, 22, 31-39].

David Fonseca

fonsi@salle.url.edu

Francisco José García-Peñalvo

fgarcia@usal.es

1 La Salle, Ramon Llull University, Sant Joan de la Salle 42, 08022 Barcelona, Spain

2 Science Faculty, Plaza de los Caídos s/n, 37008 Salamanca, Spain
Nowadays, in the educational processes, technology is ever present and allows for the incorporation and strengthening of new educational strategies, currently defined in new teaching frameworks in the last two decades [40-46]. Educators' interest in using these technologies in the teaching process involves greater engagement and an increase in student motivation in understanding content [47-50], thereby improving academic results [51]. Given this context, it is necessary to analyze where and when the learning happens, how it happens and what the learners' needs, aims and abilities are [46, 52-57]. In order to do so, it is necessary to explore existing methodologies, frameworks and tools used to access and manage knowledge and to consider whether they make it accessible for all [3].

This UAIS special issue follows the work started following the edition of a number of previous special issues [58] and the organization of four international events:

- The invited session titled "Emerging interactive systems for education," in the thematic area "Learning and Collaboration Technologies," in the context of the 19th HCI International Conference 2017, in Vancouver, Canada, with 28 papers accepted;

- The invited session titled "Learning ecosystems for academic motivation and engagement," in the thematic area "Learning and Collaboration Technologies," in the context of the 20th HCI International Conference 2018, in Las Vegas (Nevada), USA, with 22 papers accepted;

- The support in the organization of the 13th Iberian Conference on Information Systems and Technologies, in Cáceres (Spain), with more than 200 papers presented;

- The organization of the 6th Edition of Technological Ecosystems for Enhancing Multiculturality, in Salamanca (Spain), also with more than 200 oral presentations.

The development of this special issue involves three stages: 
- The first consists of the reception and evaluation of abstracts, as a way to reject those works out of the scope of the special issue. We received 55 abstracts to be evaluated, out of which 35 were selected;

- In the second stage, these papers were evaluated through a peer review process. Each paper was reviewed by three experts related to the special issue topics. The papers were distributed and assigned according to the expertise and field of study of the different reviewers;

- During the third stage, feedback was provided to the authors who have to edit and resubmit their manuscripts. A total of 19 papers were accepted after these three stages.

The main aims of the special issue address the study of how to improve universal access to digital information using: a) innovative approaches with serious games and gamification (new approaches for its incorporation in successful educational practices toward the improvement of motivation, satisfaction, user experience, accessibility, skills and competence) $[22,38,56,59]$; b) assessing teachers as designers of TEL (technology-enhanced learning) interventions with new roles (from the classic student and teacher to the new learning framework more oriented to technological ecosystems than a closed system, where the teacher is a facilitator and students are the data/content creators) [4, 9, 45, 47, 60-63]; and c) reviewing the technology and social inclusion [36, $64,65]$. The editors and authors have explored how people acquire their skills based on the idea of digital natives and immigrants, not forgetting older generations, people with disabilities and low-income groups, from a heterogeneous point of view and research [55, 66, 67].

To start, the paper of Rodríguez Sedano et al. [68] describes the design and evaluation of a graphical user interface so that a non-expert user could use a teleoperated system intuitively and without excessive training time. The authors have used a user-centered design process model to assess the usability of the system, which has been improved with their proposal. From the experiment, it is possible to conclude that the use of teleoperation systems by non-expert users can be improved defining intuitive graphic interfaces that provide visual and haptic feedback.

Huang and Chen [69] in their paper present an approach for an innovative interface for displaying and control of information for interactive experiential learning. In their study, an interactive three-dimensional (3D) holographic projection system was developed and used in a physiologybased experiential learning experiment. The main conclusions are that the gender had no significant effect on any of the four factors studied ( $p>0.05$ ). Further, the learner's experiential learning characteristics and human-computer interaction modality are described based on the results of this usability study.
The WYRED Ecosystem is a technological ecosystem developed as part of WYRED (netWorked Youth Research for Empowerment in the Digital society), a European Project funded by the Horizon 2020 program, presented by Garcia-Peñalvo et al. [70]. The main aim of the project is to provide a framework for research in which children and young people can express and explore their perspectives and interests concerning digital society. The WYRED Ecosystem supports this framework from a technological point of view. The paper presents the usability test done to evolve the Platform through the System Usability Scale (SUS). This usability test allows the identification of the weaknesses of the Platform regarding its characteristics, also allowing the corresponding improvement of the WYRED Platform, and will serve as a reference for further usability testing.

Orehovački et al. [71] discuss in their paper one of the major problems of using Massive Online Open Courses (MOOCs): the high dropout rate of students. In their study, they have examined the psychometric characteristics of the research framework which reflects the interplay of adoption determinants with respect to two representatives of social Web applications meant for collaborative work. In conclusion, the habit is the most relevant driver of adoption when social Web applications employed in MOOC are considered, because if students would use particular social Web applications for performing collaborative activities regularly, it is very likely that they would start to apply them in other private and business activities they are suitable for.

Starting a section of papers with heterogeneous approaches related to gamification, Filho et al. [72] present a card game proposed to increase the engagement of different evaluators in an evaluation process based on Heuristic Evaluation. G4NHE is a generalization of previous work (the G4H gamification) to be applied to different usability heuristics. The G4H was designed to support Nielsen's heuristic only, and the main goal of the G4NHE is to provide an engaging and ludic way to consolidate collaborative heuristic evaluation. The research presents the steps used to create the G4NHE and a guide to enable any HCI professional or student to use G4NHE gamification with any usability heuristic. As a result, this work enables gamification nonspecialists to create a gamification based on G4H (a gamification built for Nielsen heuristics) to any usability heuristic.

Villegas et al. [73] present a new methodology that was created as a method for adding user experience as an evaluation of user's behavior and includes the application of gamification as a method of increasing motivations. The study presented is based on the explanation of the method used for its creation and in the evaluation of the first results obtained before its application. One of the aims that is worked within the user experience is to evolve in the search of systems where a starting point is developed from a hypotheticodeductive system where the consultant established the 
hypothesis to be solved based on the possible behavior of the user to a system where users are also an active part of decisions. Therefore, the system applied for the design is based on a User-Centered Design system. The application allows to discover useful information in order to design a Workshop that can improve the quality of the results, increase the relevance of the resulting report and contribute efficiency versus the current systems.

The paper presented by Milenković et al. [74] focuses on the use of gamification for educating engineers in the field of biometrics. A learning platform with gamification elements was developed for the course of biometric technologies, held at the University of Belgrade. The platform combines standard gamification elements with role-playing, as it allows students to find themselves in both the role of biometric engineers and that of system attackers. The effects of the gamified approach were evaluated in the context of a biometric technologies course held at the University of Belgrade. These research study results show improvement in student motivation and learning outcomes.

Ortega-Arranz et al. [75] present a new approach that examines the students' behavior toward earning badges and how it relates to their engagement in a gamified MOOC. According to the results, the behaviors toward badges of the active students were generally positive and significantly correlated with other variables measuring their engagement (e.g., page-views, submitted tasks, forum posts), although this positive behavior seems to decrease throughout the course. Additionally, students that reported high motivation by badges at the end of the course showed a higher engagement level than those that were not attracted by badges.

To quantify confused states in logic reasoning in gamebased learning, Zhou et al. [76] propose an EEG-based methodology for assessing the user's confusion using an OpenBCI device with eight channels. In the complicated context of game play, it is difficult, and sometimes impossible, to collect the ground truth of the data in real tasks. Therefore, their research leverages cross-task and crosssubject methods to build a classifier, that is, training on the data of one standardized cognitive test paradigm (Raven's test) and testing on the data of real tasks in the game play (Sokoban Game). It provides a new possibility to create a classifier based on a small dataset. Results showed the feasibility of their proposal in the task variation of the classifier, with an accuracy of $91.04 \%$. The proposed EEG-based methodology is suitable to analyze learners' confusion on the long game-play duration and has a good adaption in real tasks.

The proposal of Compañ-Rosique et al. [77] has served to study and design new ways of making video games accessible to disabled people, giving them the chance to exercise their right to entertainment. Starting from the idea that video games were initially a form of entertainment, today this perception has changed, and many video games have been designed for a wide range of purposes including education, rehabilitation, etc. In their study, the research team presents an experience developing video games in collaboration with an association of users with cerebral palsy. This means that people affected by this disease are unable to handle the usual devices used in video games. Three adapted video games have been developed as well as a guide for designing accessible video games to people with cerebral palsy.

Starting with the idea that learning programming in College Education is hard for students, Rojas-López et al. [78] present a gamified strategy to boost significant learning as well as sustained motivation during the delivery of the course. The paper presents two interventions in the University of Mexico using the challenge-based gamification pedagogical strategy. This strategy supports the Werbach and Hunter methodology. The dynamics were emotional, social and progressive and were conducted through challenge and opportunities mechanics. The components were points, badges, avatars and a leaderboard. The main research conclusion indicates that gamification in the classroom contributed to improve the engagement with the students to succeed in solving the challenges successfully; therefore, the pedagogical strategy under scrutiny can be applied to other subjects.

The last paper related to games or gamified approaches is presented by García et al. [79], and it focuses on the development of multiplatform educational video games using a Domain-Specific Language. Video game development is a very complex task that requires programming skills and knowledge of multiple technologies, as well as lengthy and costly processes. This has hindered the adoption of educational video games in real settings, and consequently the global acceptance of educational games as a viable approach. If enthusiastic teachers can be empowered to create games to engage their students, and if these games were ready to be played in a variety of devices and platforms, it would be possible to bring a new generation of low-cost games for immediate deployment in the classroom, using the students' own devices. The authors aim to achieve this goal by creating a Domain-Specific Language for the development of multiplatform educational video games without requiring any programming skills and with a reduced time investment.

Moreira et al. [80] present a learning teaching paradigm in higher education: on the one hand, new technologies uses and, on the other, the characteristics (habits and abilities) presented by the students that arrive to universities. These factors are not compatible with the teaching methodologies commonly used to date, that is, with the traditional model (lectures) consolidated in the nineteenth century. In this context, teachers who resort to active learning have attracted a lot of attention, since this type of approach stimulates students' motivation and autonomy to acquire more 
competencies, one of the guidelines of the European Norms and Guidelines for Quality in Higher Education. Thus, as a way of responding to these challenges, an innovative pilot project was developed, from the pedagogical point of view, implemented in a first cycle course (Management and Information Systems) using active methodologies. The results obtained are very promising, since they have allowed students to engage in and out of the classroom and have resulted in a highly successful course.

Nowadays, companies and organizations require highly competitive professionals with the necessary skills to confront new challenges. However, current evaluation techniques do not allow detection of skills that are valuable in the work environment, such as collaboration, teamwork and effective communication. In their paper, Riquelme et al. [81] develop a computational environment to both analyze and visualize student discussion groups working in a collaborative way to accomplish a task. ReSpeaker devices were used to collect speech data from students, and based on the measurements, the system developed allows to visualize non-trivial information regarding interrelations between subjects in collaborative working groups; moreover, this information can support complex decision-making processes.

Closing the section of ecosystems papers, the work of Sein-Echaluce et al. [82] focuses on active learning and presents a "model 2.0" through which students create, share and use resources through different channels of the technological ecosystem. From this context, framework 3.0 was developed and tested, based on the Web 3.0 model, in which all the resources generated by students and teachers are organized and classified through an ontology which can be transferred to other subjects. Moreover, a semantic searcher system was developed that operates by drawing inferences between the elements of the ontologies. The result obtained was that both groups used in the study preserved the characteristics of learning in the 2.0 model, and the transition to the 3.0 model allowed better access to the knowledge created in the subject as well as an improvement in the searchability of resources. A relationship was also identified between model 3.0 and an improvement in students' grades.

The work of Arain et al. [83] focuses on the use of smartphones as a learning tool in education, based on the framework of mobile learning (m-learning studies), as an approach that provides enormous opportunities by connecting humans and technology resulting to better learning experiences and technology acceptance. Centered in the acceptance and use of technology model (UTAUT2), the study not only uses UTAUT2 as a theoretical framework but also extends it using five other constructs: ubiquity, information quality, system quality, appearance quality and satisfaction. A crosssectional survey was conducted in two engineering universities in Pakistan with a sample of 900 students, out of which 730 usable responses were selected for further analysis. The findings revealed that the model fits data well; the model fit indices were within the recommended thresholds. The performance expectancy, hedonic motivation, habit, ubiquity and satisfaction have a statistically significant impact on behavioral intention, and the information quality, system quality and appearance quality also have statistically significant impact on the mediator satisfaction toward m-learning acceptance.

The study by Company et al. [84] focuses on how Information and Communications Technologies (ICTs) offer new roles to teachers to improve learning processes. In this regard, learning rubrics are commonplace. The authors discuss about the design of these rubrics, which has focused mainly on scoring (summative rubrics), whereas formative rubrics have received significantly less attention. ICTs make possible electronic rubrics (e-rubrics) that enable dynamic and interactive functionalities that facilitate the adaptable and adaptive delivery of content. In their research, the authors present a case study that examines three characteristics to make formative rubrics more adaptable and adaptive: criteria dichotomization, weighted evaluation criteria and go/no-go criteria.

Mareca and Bordel [85] present a study focusing on how the educative model is changing and adapting different technological solutions. An extended solution in the universities' framework is centered in supporting activities and events about the edition of wikis and the use of Wikipedia. The paper has two objectives. First, it highlights the international educational projects in which this encyclopedia is edited and improved, especially by indicating the theme of the chosen edition, edition dates and achievements. Second, once the action framework has been introduced, the authors show a specific educational project developed with students from the Universidad Politécnica de Madrid (UPM) since 2009. Results show that editing Wikipedia produces a relevant improvement in the five proposed objectives.

The last paper of this special issue is the work of Silva et al. [86]. It starts from the idea that equal access to all software and digital content should be a reality in the Digital Era. This argument is something defended by existing regulations, norms and standards, as well as business organizations and governments. For certain groups of disabled or impaired citizens, such as the visually impaired, the existence of e-accessibility compliance represents an opportunity to integrate, in a more simple and straightforward manner, their societies. The authors propose an accessible software development model that encompasses e-accessibility incorporation as one of the development process activities. This model might represent a very interesting support tool for software development organizations and a novel resource for learning and training institutions to be able to improve their computer science and informatics students' skills on e-accessibility. 
The Guest Editors

David Fonseca, Francisco José García-Peñalvo

\section{List of reviewers}

Marc Alier, University Polytechnic of Catalonia, Spain María Alsina, GRETEL Research Group, La Salle Ramon Llull University, Spain

Hector R. Amado-Salvatierra, GES Department, Universidad Galileo, Guatemala

Daniel Amo, GRETEL Research Group, La Salle Ramon Llull University, Spain

Xavier Canaleta, Vice-Dean in Educational Innovation at La Salle, Universitat Ramon Llull, Spain

Jean-Marie Chatelet, University of Lille, France

Miguel Angel Conde-González, Associated Professor, University of Leon, Spain

Juan Cruz-Benito, GRIAL Research Group, University of Salamanca, Spain

Hilda Angélica Del Carpio Ramos, Universidad Nacional Pedro Ruiz Gallo de Lambayeque, Peru

Emiliano Díez, Associated Professor, University of Salamanca, Spain

Juan Manuel Dodero, D Associated Professor, Department of Informatics Engineering, University of Cádiz, Spain

Jorge Dorribo, Associated Professor Purdue University, Indiana, USA

Alicia García-Holgado, GRIAL Research Group, University of Salamanca, Spain

Leonardo David Glasserman Morales, School of Humanities and Education, Tec de Monterrey, México

Carina Soledad González González, Associated Profes-

sor, Computer Science Department, University of La Laguna, Spain

Dai Griffiths, Full Professor of Educational Cybernetics at University of Bolton, UK

Luis Hernández, Associated Professor and Manager of Research Group in advanced visualization at Universidade da Coruña, Spain

Hsinfu Huang, Department of Industrial Design, National Yunlin University of Science and Technology, Taiwan

Zahid Hussain, Professor and Dean at Technische Universität Graz, Austria

Ignasi Iriondo, GRETEL Research Group, La Salle

Ramon Llull University, Spain

Jorge Joo, Metropolitan University of Science in Education, History and Geography, Chile

Elena Jurado, GRETEL Research Group, La Salle Ramon Llull University, Spain

Emiliano Labrador, GRETEL Research Group, La Salle Ramon Llull University, Spain

Faraon Llorens, Associated Professor in Artificial Intelligence and Computation at Alicante University, Spain
Samuel Marcos, GRIAL Research Group, University of Salamanca, Spain

José Luís Bandeira Rodrigues Martins, Assistance Professor of Trás-os-Montes e Alto Douro, Vila Real, Portugal.

Ravi Mokashi, Professor and Dean in the Department of Design of Indian Institute of Technology Guwahati, India Miroslav Minovic, Assistant Professor at University of Belgrade, Serbia

Rafael Molina, Associated Professor in Artificial Intelligence and Computation at Alicante University, Spain

Fernando Moreira, Associated Professor at Economics, Management and Informatics Department of Universidade Portucalense, Portugal

Roberto Muñoz, Catholic University of Valparaiso, Chile Claudia Navarro Corona, School of Humanities and Education, Tec de Monterrey, México

Walter Nuninger, University of Lille, France

Tihomir Orehovački, Assistant Professor at Juraj Dobrila University of Pula, Croatia

Salvatore Flavio Pileggi, Research Fellow in the Schools of Information Technology and Electrical Engineering at the University of Queensland, Australia

Paola Ricaurte, Associated Researcher, School of Humanities and Education, Tec de Monterrey, México

Elvira Rincon, School of Humanities and Education, Tec de Monterrey, México

Ernest Redondo, Full Professor and vice-dean of Architecture at Polytechnic University of Catalonia, Spain

Arturo Rojas, Technological University of Puebla, México

José Carlos Sánchez-Prieto, GRIAL Research Group, University of Salamanca, Spain

José Luis Sierra, Associated Professor, Department of Software Engineering and AI, University Complutense of Madrid, Spain

Marisa Sein-Echaluce, Associated Professor at Department of Applied Mathematics, Zaragoza University, Spain

Martín Adalberto Tena, Science and Information Department, University of Salamanca, Spain

Roberto Therón, GRIAL Research Group, University of Salamanca, Spain

Ricardo Torres-Kompen, GRETEL Research Group, La Salle Ramon Llull University, Spain

Andrea Vázquez-Ingelmo, GRIAL Research Group, University of Salamanca, Spain

Teija Vainio, HCI and User Experience Design researcher at University of Tampere, Finland

Andrea Valente, Associated Professor at Southern Denmark University, Denmark

Klinge Orlando Villalba Condori, Nacional University of San Agustín, Perú 
Eva Villegas, GRETEL Research Group, La Salle Ramon Llull University, Spain

\section{References}

1. Conde, M.Á., Fonseca, D.: Information society skills: is knowledge accessible for all? Part I. Univers. Access Inf. Soc. 17, 223227 (2018). https://doi.org/10.1007/s10209-017-0547-7

2. Fonseca, D., Conde, M.Á.: Information society skills: is knowledge accessible for all? Part II. Univers. Access Inf. Soc. 17, 447-451 (2018). https://doi.org/10.1007/s10209-017-0554-8

3. Fonseca, D., Conde, M.Á., García-Peñalvo, F.J.: Improving the information society skills: is knowledge accessible for all? Univers. Access Inf. Soc. (2017). https://doi.org/10.1007/s1020 9-017-0548-6

4. Redondo, E., Fonseca, D., Giménez, L., Santana, G., Navarro, I.: Alfabetización digital para la enseñanza de la arquitectura. Un estudio de caso. Arquiteturarevista 8, 76-87 (2012). https://doi. org/10.4013/arq.2012.81.08

5. Navarro Delgado, I., Fonseca Escudero, D.: Nuevas tecnologías de visualización para mejorar la representación de arquitectura en la educación. Archit. City Environ. 12, 219-238 (2017). https:// doi.org/10.5821/ace.12.34.5290

6. Fonseca, D., Redondo, E., Valls, F., Villagrasa, S.: Technological adaptation of the student to the educational density of the course. A case study: 3D architectural visualization. Comput. Hum. Behav. 72, 599-611 (2017). https://doi.org/10.1016/j. chb.2016.05.048

7. Fonseca, D., Martí, N., Redondo, E., Navarro, I., Sánchez, A.: Relationship between student profile, tool use, participation, and academic performance with the use of Augmented Reality technology for visualized architecture models. Comput. Hum. Behav. 31, 434-445 (2014). https://doi.org/10.1016/j.chb.2013.03.006

8. Fonseca, D., Redondo, E., Villagrasa, S.: Mixed-methods research: a new approach to evaluating the motivation and satisfaction of university students using advanced visual technologies. Univers. Access Inf. Soc. 14, 311-332 (2015). https://doi. org/10.1007/s10209-014-0361-4

9. Clarke, A., Nielsen, W., Collins, J., Mena, J., Hoban, G., O'Shea, S.: Australia's supervising teachers: motivators and challenges to inform professional learning. Asia-Pacific J. Teachnol. Educ. 45, 346-368 (2017). https://doi.org/10.1080/1359866x.2017.1304527

10. García-Peñalvo, F.J.: ¿Son conscientes las universidades de los cambios que se están produciendo en la Educación Superior?/ Are Universities Aware of the Changes that are Occurring in Higher Education? Educ. Knowl. Soc. 17, 7-13 (2016). https:// doi.org/10.14201/eks2016174713

11. Gordillo, A., Gallego, D., Barra, E., Quemada, J.: The city as a learning gamified platform. In: Proceedings-Frontiers in Education Conference, FIE (2013)

12. Margaryan, A., Littlejohn, A., Vojt, G.: Are digital natives a myth or reality? University students' use of digital technologies. Comput. Educ. 56, 429-440 (2011). https://doi.org/10.1016/j.compe du.2010.09.004

13. Freeman, S., Eddy, S.L., McDonough, M., Smith, M.K., Okoroafor, N., Jordt, H., Wenderoth, M.P.: Active learning increases student performance in science, engineering, and mathematics. Proc. Natl. Acad. Sci. 111, 8410-8415 (2014). https://doi.org/10.1073/ pnas. 1319030111

14. Colardyn, D., Bjornavold, J.: Validation of formal, non-formal and informal learning: policy and practices in EU Member
States 1. Eur. J. Educ. 39, 69-89 (2004). https://doi.org/10.111 1/j.0141-8211.2004.00167.x

15. Harrop, D., Turpin, B.: A study exploring learners' informal learning space behaviors, attitudes, and preferences a study exploring learners' informal learning. New Rev. Acad. Librariansh. 1, 37-41 (2013). https://doi.org/10.1080/13614 533.2013.740961

16. Banks, J., Au, K., Ball, a, Bell, P., Gordon, E., Gutiérrez, K., Heath, S.B., Lee, C., Lee, Y., Mahiri, J., et al.: Learning in and out of school in diverse environments: Life-long, life-wide, lifedeep. Seattle, WA LIFE Cent. (The Learn. Informal Form. Environ. Center) Cent. Multicult. Educ. Univ. Washington. Retrieved Sept. (2007). https://doi.org/10.1118/1.3641645

17. Fidalgo-Blanco, Á., Sein-Echaluce, M.L., García-Peñalvo, F.J.: Ontological flip teaching: a flip teaching model based on knowledge management. Univers. Access Inf. Soc. 17, 475-489 (2018). https://doi.org/10.1007/s10209-017-0556-6

18. García-Peñalvo, F.J., Hernández-García, Á., Conde, M.Á., Fidalgo-Blanco, Á., Sein-Echaluce, M.L., Alier-Forment, M., Llorens-Largo, F., Iglesias-Pradas, S.: Enhancing education for the knowledge society era with learning ecosystems. In: Open Source Solutions for Knowledge Management and Technological Ecosystems, pp. 1-24 (2017)

19. Sanchez-Sepulveda, M., Fonseca, D., Franquesa, J., Redondo, E.: Virtual interactive innovations applied for digital urban transformations. Mixed approach. Future Gener. Comput. Syst. 91, 371-381 (2019). https://doi.org/10.1016/j.futur e.2018.08.016

20. Fonseca, D., Villagrasa, S., Navarro, I., Redondo, E., Valls, F., Llorca, J., Gómez-Zevallos, M., Ferrer, A., Calvo, X.: Student motivation assessment using and learning virtual and gamified urban environments. In: ACM International Conference Proceeding Series (2017)

21. García-Peñalvo, F.J.: Open access myths and realities. Educ. Knowl. Soc. (2017). https://doi.org/10.14201/eks2017181720

22. Valls, F., Redondo, E., Fonseca, D., Garcia-Almirall, P., Subirós, J.: Videogame technology in architecture education. In: Kurosu, M. (ed.) Lecture Notes in Computer Science (including subseries Lecture Notes in Artificial Intelligence and Lecture Notes in Bioinformatics), pp. 436-447. Springer, Toronto (2016)

23. García-Peñalvo, F.J.: Technological Ecosystems. Rev. Iberoam. Tecnol. Aprendiz. 11, 31-32 (2016). https://doi.org/10.1109/ RITA.2016.2518458

24. Villagrasa, S., Fonseca, D., Redondo, E., Duran, J.: Teaching case of gamification and visual technologies for education. J. Cases Inf. Technol. (2014). https://doi.org/10.4018/jcit.2014100104

25. Benitti, F.B.V.: Exploring the educational potential of robotics in schools: a systematic review. Comput. Educ. 58, 978-988 (2012). https://doi.org/10.1016/j.compedu.2011.10.006

26. Dabbagh, N., Kitsantas, A.: Personal Learning Environments, social media, and self-regulated learning: a natural formula for connecting formal and informal learning. Internet High. Educ. 15, 3-8 (2012). https://doi.org/10.1016/j.iheduc.2011.06.002

27. Zhou, C.: Integrating creativity training into Problem and Project-Based Learning curriculum in engineering education. Eur. J. Eng. Educ. 37, 488-499 (2012). https://doi.org/10.1080/03043 797.2012.714357

28. Casquero, O., Portillo, J., Ovelar, R., Benito, M., Romo, J.: iPLE Network: an integrated eLearning 2.0 architecture from a university's perspective. Interact. Learn. Environ. 18, 293-308 (2010). https://doi.org/10.1080/10494820.2010.500553

29. Attwell, G.: Personal learning environments-the future of eLearning ? eLearning Pap. 2, 1-8 (2007). https://doi. org/10.1080/19415257.2011.643130 
30. Petre, M., Price, B.: Using robotics to motivate "back door" learning. Educ. Inf. Technol. 9, 147-158 (2004). https://doi. org/10.1023/B:EAIT.0000027927.78380.60

31. García-Peñalvo, F.J., Fidalgo-Blanco, Á., Sein-Echaluce, M.L.: An adaptive hybrid MOOC model: disrupting the MOOC concept in higher education. Telemat. Inform. 35, 1018-1030 (2018). https ://doi.org/10.1016/j.tele.2017.09.012

32. Joo-Nagata, J., Martinez Abad, F., García-Bermejo Giner, J., García-Peñalvo, F.J.: Augmented reality and pedestrian navigation through its implementation in m-learning and e-learning: evaluation of an educational program in Chile. Comput. Educ. 111, 1-17 (2017). https://doi.org/10.1016/j.compedu.2017.04.003

33. Ramírez-Montoya, M.-S., Hernández, D.D.C.R.: Inverted learning environments with technology, innovation and flexibility. J. Inf. Technol. Res. 9, 18-33 (2016). https://doi.org/10.4018/jitr.20160 10102

34. Ramírez-Montoya, M.S.: Innovación abierta, interdisciplinaria y colaborativa para formar en sustentablidad energética a través de MOOCs e investigación educativa. Educ. Knowl. Soc. 19, 11 (2019). https://doi.org/10.14201/eks20181941130

35. Sánchez Riera, A., Redondo, E., Fonseca, D.: Geo-located teaching using handheld augmented reality: good practices to improve the motivation and qualifications of architecture students. Univers. Access Inf. Soc. 14, 363-374 (2015). https://doi.org/10.1007/ s10209-014-0362-3

36. Fonseca, D., Valls, F., Redondo, E., Villagrasa, S.: Informal interactions in 3D education: citizenship participation and assessment of virtual urban proposals. Comput. Hum. Behav. 55, 504-518 (2016). https://doi.org/10.1016/j.chb.2015.05.032

37. Valls, F., Redondo, E., Fonseca, D., Torres-Kompen, R., Villagrasa, S., Martí, N.: Urban data and urban design: A data mining approach to architecture education. Telemat. Inform. 35(4), 1039-1052 (2018). https://doi.org/10.1016/j.tele.2017.09.015

38. Fonseca, D., Villagrasa, S., Navarro, I., Redondo, E., Valls, F., Sánchez, A.: Urban gamification in architecture education. In: Rocha, Á., Correia, A.M., Adeli, H., Reis, L.P., Costanzo, S. (eds.) Advances in Intelligent Systems and Computing, pp. 335-341. Springer, Cham (2017)

39. Vicent, L., Villagrasa, S., Fonseca, D., Redondo, E.: Virtual learning scenarios for qualitative assessment in higher education 3D arts. J. Univers. Comput. Sci. 21, 1086-1105 (2015)

40. Dede, C.: Emerging influences of information technology on school curriculum. J. Curric. Stud. 32, 281-303 (2000). https:// doi.org/10.1080/002202700182763

41. Huang, F., Teo, T., Sánchez-Prieto, J.C., García-Peñalvo, F.J., Olmos-Migueláñez, S.: Cultural values and technology adoption: a model comparison with university teachers from China and Spain. Comput. Educ. 133, 69-81 (2019). https://doi. org/10.1016/j.compedu.2019.01.012

42. Ramírez-Montoya, M.S., García-Peñalvo, F.-J.: Co-creación e innovación abierta: Revisión sistemática de literatura, Co-creation and open innovation: Systematic literature review, https://www. revistacomunicar.com/index.php?contenido=detalles\&numer $\mathrm{o}=54 \&$ articulo $=54-2018-01(2018)$

43. Peredo, A., Redondo, E., Olivares, A., Navarro, I., Valls, F., Villagrasa, S., Fonseca, D.: Educational qualitative assessment of augmented reality models and digital sketching applied to urban planning. In: ACM International Conference Proceeding Series, pp. 447-454 (2014)

44. Fonseca Escudero, D., Redondo, E., Sánchez, A., Valls, F.: Educating Urban Designers using Augmented Reality and Mobile Learning Technologies/Formación de Urbanistas usando Realidad Aumentada y Tecnologías de Aprendizaje Móvil. RIED 20, 141 (2017). https://doi.org/10.5944/ried.20.2.17675

45. García-Holgado, A., García-Peñalvo, F.J.: Human interaction in learning ecosystems based on open source solutions. In: Lecture
Notes in Computer Science (including subseries Lecture Notes in Artificial Intelligence and Lecture Notes in Bioinformatics), pp. 218-232 (2018)

46. Campanyà, C., Fonseca, D., Martí, N., Peña, E., Ferrer, A., Llorca, J.: Identification of significant variables for the parameterization of structures learning in architecture students. In: Rocha, Á., Adeli, H., Reis, L., Costanzo, S. (eds.) Trends and Advances in Information Systems and Technologies. WorldCIST'18 2018. Advances in Intelligent Systems and Computing, vol. 747, pp. 298-306. Springer, Cham (2018). https://doi. org/10.1007/978-3-319-77700-9_30

47. Kreijns, K., Van Acker, F., Vermeulen, M., Van Buuren, H.: What stimulates teachers to integrate ICT in their pedagogical practices? The use of digital learning materials in education. Comput. Hum. Behav. 29, 217-225 (2013). https://doi. org/10.1016/j.chb.2012.08.008

48. Shen, C.-X., Liu, R.-D., Wang, D.: Why are children attracted to the Internet? The role of need satisfaction perceived online and perceived in daily real life. Comput. Hum. Behav. 29, 185-192 (2013). https://doi.org/10.1016/j.chb.2012.08.004

49. Fonseca, D., Redondo, E., Valls, F., Villagrasa, S.: Technological adaptation of the student to the educational density of the course. A case study: 3D architectural visualization. Comput. Hum. Behav. 72, 599-611 (2017). https://doi.org/10.1016/j. chb.2016.05.048

50. Llorca, J., Zapata, H., Redondo, E., Alba, J., Fonseca, D.: Bipolar laddering assessments applied to urban acoustics education. In: Advances in Intelligent Systems and Computing, pp. 287297 (2018)

51. Prensky, M.: From digital natives to digital wisdom: introduction. In: From Digital Natives to Digital Wisdom: Hopeful Essays for 21st Century Education, pp. 1-9 (2012)

52. Alier, M., Redondo, E., Valls, A., Fonseca, D., García-Peñalvo, F., Amo, D., Canaleta, X.: Using web analytics tools to improve the quality of educational resources and the learning process of students in a gamified situation. In: INTED2018 Proceedings, pp. 5824-5829 (2018)

53. Filvà, D.A., Forment, M.A., García-Peñalvo, F.J., Escudero, D.F., Casañ, M.J.: Clickstream for learning analytics to assess students' behavior with Scratch. Future Gener. Comput. Syst. 93, 673-686 (2019). https://doi.org/10.1016/j.futur e. 2018.10 .057

54. Gómez-Aguilar, D.-A., García-Peñalvo, F.-J., Therón, R.: Analítica visual en e-learning. El Prof. la Inf. 23, 236-245 (2014). https://doi.org/10.3145/epi.2014.may.03

55. Aguilar, D.A.G., Therón, R., Garc ia-Peñalvo, F.: Semantic spiral timelines used as support for e-learning. J. Univers. Comput. Sci. 15, 1526-1545 (2009)

56. Torres-Toukoumidis, Á., Ramírez-Montoya, M.S., Romero-Rodríguez, L.M.: Valoración y evaluación de los Aprendizajes Basados en Juegos (GBL) en contextos e-learning. Educ. Knowl. Soc. 19, 109 (2019). https://doi.org/10.14201/eks201819410912 8

57. Fonseca D., Montero J.A., Guenaga M., Mentxaka I.: Data analysis of coaching and advising in undergraduate students. An analytic approach. In: Zaphiris, P., Ioannou, A. (eds.) Learning and Collaboration Technologies. Technology in Education. LCT 2017. Lecture Notes in Computer Science, vol. 10296, pp. 269-280. Springer, Cham (2017). https://doi.org/10.1007/9783-319-58515-4_21

58. Fonseca, D.: User experience and access using augmented and multimedia technologies: special issue of UXeLATE (2012) Workshop and HCI International Conference (2013) special sessions. Univers. Access Inf. Soc. (2014). https://doi.org/10.1007/ s10209-014-0360-5 
59. Dias, L.P.S., Barbosa, J.L.V., Vianna, H.D.: Gamification and serious games in depression care: a systematic mapping study. Telemat. Inform. 35(1), 213-224 (2018). https://doi. org/10.1016/j.tele.2017.11.002

60. Mena, J., Hennissen, P., Loughran, J.: Developing pre-service teachers' professional knowledge of teaching: the influence of mentoring. Teach. Teach. Educ. 66, 47-59 (2017). https://doi. org/10.1016/j.tate.2017.03.024

61. García-Holgado, A., García-Peñalvo, F.J.: Validation of the learning ecosystem metamodel using transformation rules. Future Gener. Comput. Syst. 91, 300-310 (2019). https://doi. org/10.1016/j.future.2018.09.011

62. García-Peñalvo, F.J.: Ecosistemas tecnológicos universitarios. UniversiTIC. 164-170 (2018)

63. García-Valcárcel, A., Mena, J.: Information technology as a way to support collaborative learning. J. Inf. Technol. Res. 9, 1-17 (2016). https://doi.org/10.4018/jitr.2016010101

64. García-Holgado, A., Yiğit, Ö., Zangrando, V., Sánchez-Prieto, J.C., García-Holgado, L., García-Peñalvo, F.J.: Inclusion of the students in schools with an intercultural profile. In: GarcíaPeñalvo, F.J. (ed.) TEEM'18 Proceedings of the Sixth International Conference on Technological Ecosystems for Enhancing Multiculturality, pp. 235-241. ACM, Salamanca (Spain) (2018)

65. Marcos-Pablos, S., García-Peñalvo, F.: Technological ecosystems in care and assistance: a systematic literature review. Sensors 19, 708 (2019). https://doi.org/10.3390/s19030708

66. Fidalgo-Blanco, Á., Sein-Echaluce, M.L., García-Peñalvo, F.J., Conde, M.Á.: Using learning analytics to improve teamwork assessment. Comput. Hum. Behav. 47, 149-156 (2015). https:// doi.org/10.1016/j.chb.2014.11.050

67. Peña, E., Fonseca, D., Martí, N.: Relationship between learning indicators in the development and result of the building engineering degree final project. In: ACM International Conference Proceeding Series, pp. 335-340 (2016)

68. Rodríguez Sedano, F.J., Conde, M.A., Ponsa, P., Muñoz, L.M., Llamas-Fernández, C.: Design and evaluation of a graphical user interface for facilitating expert knowledge transfer: a teleoperation case study. Univers. Access Inf. Soc. 18(3), (2019). https://doi. org/10.1007/s10209-019-00670-1

69. Huang, H., Chen, C.-W.: Creating different learning experiences: assessment of usability factors in an interactive three-dimensional holographic projection system for experiential learning. Univers. Access Inf. Soc. 18(3), (2019). https://doi.org/10.1007/s1020 9-019-00671-0

70. García-Peñalvo, F.J., Vázquez-Ingelmo, A., García-Holgado, A., Seoane-Pardo, A.M.: Analyzing the usability of the WYRED Platform with undergraduate students to improve its features. Univers. Access Inf. Soc. 18(3), (2019). https://doi.org/10.1007/s1020 9-019-00672-Z

71. Orehovački, T., Etinger, D., Babić, S.: Modelling an interplay of adoption determinants with respect to social Web applications used in massive online open courses. Univers. Access Inf. Soc. 18(3), (2019). https://doi.org/10.1007/s10209-019-00673-y

72. Filho, J.C. de S., Monteiro, I.T., Jucá, P.M.: Game for aNy heuristic evaluation (G4NHE): a generalization of the G4H gamification considering different sets of usability heuristics. Univers. Access Inf. Soc. 18(3), (2019). https://doi.org/10.1007/s10209-019-00674 $-x$

73. Villegas, E., Labrador, E., Fonseca, D., Fernández-Guinea, S.: Methodology I'M IN applied to workshop: successful educational practice for consultants in user experience with gamification fields. Univers. Access Inf. Soc. 18(3), (2019). https://doi. org/10.1007/s10209-019-00675-w

74. Milenković, I., Šošević, U., Simić, D., Minović, M., Milovanović, M.: Improving student engagement in a biometric classroom: the contribution of gamification. Univers. Access Inf. Soc. 18(3), (2019). https://doi.org/10.1007/s10209-019-00676-9

75. Ortega-Arranz, A., Er, E., Martínez-Monés, A., Bote-Lorenzo, M.L., Asensio-Pérez, J.I., Muñoz-Cristóbal, J.A.: Understanding student behavior and perceptions toward earning badges in a gamified MOOC. Univers. Access Inf. Soc. 18(3), (2019). https://doi. org/10.1007/s10209-019-00677-8

76. Zhou, Y., Xu, T., Li, S., Shi, R.: Beyond engagement: an EEGbased methodology for assessing user's confusion in an educational game. Univers. Access Inf. Soc. 18(3), (2019). https://doi. org/10.1007/s10209-019-00678-7

77. Compañ-Rosique, P., Molina-Carmona, R., Gallego-Durán, F., Satorre-Cuerda, R., Villagrá-Arnedo, C., Llorens-Largo, F.: A guide for making video games accessible to users with cerebral palsy. Univers. Access Inf. Soc. 18(3), (2019). https://doi. org/10.1007/s10209-019-00679-6

78. Rojas-López, A., Rincón-Flores, E.G., Mena, J.J., García-Peñalvo, F.J., Ramírez-Montoya, M.S.: Engagement in the course of programming in higher education through the use of gamification. Univers. Access Inf. Soc. 18(3), 2019. https://doi.org/10.1007/ s10209-019-00680-z

79. García, C.G., Núñez-Valdeza, E.R., Moreno-Gerb, P., Crespo, R.G., Bustelo, C.P., Lovelle, J.M.C.: Agile development of multiplatform educational video games using a Domain-Specific Language. Univers. Access Inf. Soc. 18(3), (2019). https://doi. org/10.1007/s10209-019-00681-y

80. Moreira, F., Ferreira, M.J., Pereira, C.S., Gomes, A.S., Collazos, C., Fonseca, D.: ECLECTIC as a learning ecosystem for higher education disruption. Univers. Access Inf. Soc. 18(3), (2019). https://doi.org/10.1007/s10209-019-00682-x

81. Riquelme, F., Muñoz, R., MacLean, R., Villarroel, R., Barcelos, T.S., Albuquerque, V.H.C. de: Using multimodal learning analytics to study collaboration on discussion groups. Univers. Access Inf. Soc. 18(3), (2019). https://doi.org/10.1007/s10209-019-00683 $-\mathrm{W}$

82. Sein-Echaluce, M., Fidalgo-Blanco, Á., Escaño, J.E.: Technological ecosystems and ontologies for an educational model based on Web 3.0. Univers. Access Inf. Soc. 18(3), (2019). https://doi. org/10.1007/s10209-019-00684-9

83. Arain, A.A., Hussain, Z., Rizvi, W.H., Vighio, M.S.: Extending UTAUT2 toward acceptance of mobile learning in the context of higher education. Univers. Access Inf. Soc. 18(3), (2019). https ://doi.org/10.1007/s10209-019-00685-8

84. Company, P., Otey, J., Agost, M.-J., Contero, M., Camba, J.D.: Teachers as designers of formative e-rubrics: a case study on the introduction and validation of go/no-go criteria. Univers. Access Inf. Soc. 18(3), (2019). https://doi.org/10.1007/s10209-019-00686 $-7$

85. Mareca, P., Bordel, B.: The educative model is changing: toward a student participative learning framework 3.0-editing Wikipedia in the higher education. Univers. Access Inf. Soc. 18(3), (2019). https://doi.org/10.1007/s10209-019-00687-6

86. Silva, J.S., Martins, J., Gonçalves, R., Branco, F., Pereira, A., Au-Yong-Oliveira, M.: Accessible software development: a conceptual model proposal. Univers. Access Inf. Soc. 18(3), (2019). https://doi.org/10.1007/s10209-019-00688-5

Publisher's Note Springer Nature remains neutral with regard to jurisdictional claims in published maps and institutional affiliations. 